\title{
MENYIKAPI INFLATION TARGETING DALAM PROSES PEMULIHAN EKONOMI : SUATU TINJAUAN TEORI
}

\author{
Edi Susianto*
}

\section{PENDAHULUAN}

Undang-undang No. 23 tahun 1999 tentang Bank Indonesia telah memberikan dimensi yang lebih fokus dan jelas mengenai tujuan yang ingin dicapai oleh Bank Indonesia. Undangundang dimaksud, sebagaimana tertuang dalam Pasal 7, menegaskan tujuan tunggal Bank Indonesia yaitu mencapai dan memelihara kestabilan nilai rupiah. Kestabilan nilai rupiah dapat diartikan dalam dua pemahaman yaitu kestabilan nilai rupiah terhadap nilai barang dan jasa di dalam negeri yang tercermin dalam angka inflasi, dan kestabilan nilai rupiah terhadap mata uang lain yang tercermin dalam angka nilai tukar/kurs. Oleh karena sejak 14 Agustus 1997 pemerintah dan Bank Indonesia menetapkan bahwa penentuan nilai tukar rupiah ditentukan oleh mekanisme pasar (free floating system), maka kestabilan nilai rupiah lebih banyak ditujukan kepada rendah dan stabilnya laju inflasi.

Menyikapi Pasal 7 UU No. 23 tahun 1999, tampaknya Bank Indonesia telah menempatkan "inflasi" sebagai anchor/landasan dalam kebijakan moneternya, dengan menetapkan suatu target inflasi sebagai acuan dalam pelaksanaan kebijakan moneter Bank Indonesia. Sebagaimana telah kita ketahui, pada tahun 2000 Bank Indonesia telah menetapkan target inflasi, diluar pengaruh kebijakan harga dan pendapatan Pemerintah 35\% dan untuk tahun 2001 berkisar antara 4-6\%. Secara teoritis, menempatkan Inflasi sebagai anchor memberikan manfaat diantaranya: (i) mudah dipahami oleh masyarakat, karena masyarakat hanya akan melihat ukuran keberhasilannya pada pencapaian laju inflasi. (ii) dapat menciptakan ekspektasi yang rendah terhadap inflasi sehingga pada akhirnya dapat menghasilkan tingkat inflasi aktual (actual inflation) sesuai yang diinginkan. (iii) dapat menghindari kemungkinan munculnya kebijakan-kebijakan yang dapat menimbulkan deviasi terhadap pencapaian target inflasi (discretionary policy).

* Analis Biro Gubernur

Penulis mengucapkan terimakasih kepada Sdr. Doddy Zulferdi, analis di DKM, yang telah memberikan waktunya untuk mendiskusikan makalah ini, dan terimakasih kepada Sdr. Ismail Riyadi, Analis Yunior Biro Gubernur, yang telah membantu penyediaan data. 
Sementara di sisi lain, terdapat dilema terutama antara pertimbangan kepentingan pertumbuhan ekonomi yang tinggi dengan laju inflasi yang rendah. Dalam kondisi ekonomi yang sedang krisis, maka tentunya pemerintah akan menerapkan kebijakan yang cenderung ekspansif guna mendorong terciptanya pertumbuhan ekonomi yang cepat. Namun dampak dari kebijakan pemerintah yang ekspansif cenderung memberikan tekanan-tekanan terhadap inflasi. Sementara, di sisi lain bank sentral melalui penetapan inflation targeting, cenderung mengarahkan kebijakannya untuk menciptakan inflasi yang rendah dan stabil.

Selain itu, dalam situasi berlangsungnya proses pemulihan ekonomi, yang dirasakan telah terjadi sejak pertengahan 1999, pencapaian target inflasi yang telah ditetapkan pada tingkat yang rendah memberikan tantangan tersendiri, ditambah bahwa salah satu mesin pendorong pertumbuhan ekonomi adalah berasal dari sisi permintaan masyarakat. Sementara di sisi lain, dengan masih belum kondusifnya situasi sosial, politik dan keamanan, maka hal tersebut tampaknya masih menimbulkan keengganan bagi para investor untuk menanamakan dananya di Indonesia, sehingga menyebabkan pengembangan sektor produksi masih sangat tersendat. Sebagaimana dikatahui peningkatan konsumsi masyarakat tanpa diimbangi peningkatan produksi cenderung memberikan tekanan-tekanan pada peningkatan harga secara umum.

Adanya hasrat pemerintah yang lebih mengutamakan pertumbuhan ekonomi dan adanya suatu kenyataan bahwa pertumbuhan ekonomi Indonesia lebih didorong oleh tingkat konsumsi masyarakat, memberikan tantangan tersendiri bagi Bank Indonesia dalam penetapan target tingkat inflasi dan bagaimana pencapaiannya. Dalam kaitan itu, menjadi suatu pertanyaan sejauh mana target inflasi yang telah ditetapkan sudah memperhitungkan dua permasalahan tersebut.

Makalah ini menjelaskan secara teoritis bagaimana kaitannya antara menetapkan target inflasi ditengah-tengah proses pemulihan ekonomi dengan dorongan untuk menciptakan inflation shock sebagai dampak dari pemulihan ekonomi. Makalah ini akan terdiri dari empat bagian. Bagian kedua makalah ini menjelaskan bagaimana dasar berpikir pemerintah (termasuk bank sentral) dan masyarakat dalam pelaksanaan inflation targeting. Pada bagian ketiga, sejauhmana pemerintah/bank sentral menghadapi godaan untuk menciptakan surprise inflation. Bagian ketiga menjelaskan model-model penetapan inflation targeting sekaligus bagaimana mengakomodir dampak dari proses pemulihan ekonomi terhadap model inflation targeting.

\section{KERANGKA TEORI PEMBENTUKAN INFLASI}

Barro \& Gordon (1983) menggambarkan mekanisme pembentukan inflasi sebagai sebuah interaksi antara preferensi pemerintah dengan preferensi masyarakat. Barro \& 
Gordon merepresentasikan preferensi pemerintah dengan suatu fungsi matematik yang menggambarkan sejauh mana pemerintah dapat meminimalkan kerugian yang ditimbulkan dari inflasi yang disebut government's loss function. Government's loss function menggambarkan kerugian yang diperoleh pemerintah dari surprise inflation yang diciptakannya, yang secara matematis diterjemahkan menjadi:

$$
\mathrm{Z}_{\mathrm{t}}=(\mathrm{a} / 2)\left(\pi_{\mathrm{t}}\right)^{2}-\mathrm{b}\left(\pi_{\mathrm{t}}-\pi_{\mathrm{t}}^{\mathrm{e}}\right)
$$

keterangan :

$\pi_{\mathrm{t}}=$ inflation rate, $\pi_{\mathrm{t}}^{\mathrm{e}}=$ expected inflation rate, $\mathrm{a}$ dan $\mathrm{b}=$ constant

dimana $(\mathrm{a} / \mathbf{2})\left(\boldsymbol{\pi}_{\mathrm{t}}\right)^{2}$ mencerminkan biaya yang harus ditanggung oleh pemerintah oleh adanya inflasi. Biaya tersebut bersifat meningkat (increasing rate) artinya apabila terdapat peningkatan inflasi $\left(\boldsymbol{\pi}_{\mathrm{t}}\right)$ maka akan menimbulkan biaya yang lebih besar dari peningkatan inflasi itu sendiri. Dalam kenyataan sehari-hari memang dirasakan bahwa apabila terdapat peningkatan inflasi maka akan menimbulkan tuntutan terhadap peningkatan Gaji PNS, tuntutan peningkatan Upah Minimum Regional (UMR) dan sebagainya. Sementara fungsi $\mathbf{b}\left(\boldsymbol{\pi}_{\mathbf{t}}-\boldsymbol{\pi}_{\mathbf{t}}{ }^{\mathrm{e}}\right)$ adalah manfaat yang diperoleh pemerintah dengan menciptakan inflation shock/ surprise inflation. Inflasi yang diciptakan pemerintah baik melalui kebijakan fiskal maupun moneter dianggap dapat memberikan rangsangan bagi peningkatan kegiatan ekonomi sehingga diharapkan dapat menekan tingkat pengangguran. Apabila manfaat yang diperoleh dari menciptakan surprise inflation lebih besar dari biayanya, maka nilai $Z_{t}$ akan negatif yang secara teoritis akan menggoda pemerintah untuk mengenakan surprise inflation.

Sementara preferensi masyarakat diwakili oleh persamaan philip yang secara matematis disimbolkan sebagai berikut:

$$
\mathrm{U}=\mathrm{U}_{\mathrm{n}}-\mathrm{a}\left(\pi_{\mathrm{t}}-\pi_{\mathrm{t}}^{\mathrm{e}}\right)
$$

dimana $\mathrm{U}_{\mathrm{n}}$ adalah normal unemployment rate

Apabila terdapat peningkatan actual inflation $\left(\pi_{\mathrm{t}}\right)$ sebagai akibat dari keberadaan surprise inflation yang diciptakan oleh Pemerintah/bank sentral, maka unexpected inflation, $\left(\pi_{t}-\pi_{t}{ }^{e}\right)$, menjadi semakin tinggi yang akhirnya dapat menekan tingkat pengangguran (U).

Kekuatan tarik menarik antara preferensi pemerintah dan preferensi masyarakat akan membentuk suatu tingkat inflasi dan tingkat pengangguran tertentu. Sementara itu, di dalam 
preferensi pemerintah itu sendiri terdapat kekuatan tarik menarik antara pertimbangan biaya inflasi dan manfaat dari inflasi. Apabila pemerintah berpikir bahwa manfaat dari surprise inflation yang diciptakannya akan memberikan manfaat yang lebih besar dari biaya yang ditimbulkan maka dorongan untuk menciptakan surprise inflation sangat tinggi. Selain itu, dorongan dari masyarakat kepada pemerintah untuk menekan tingkat pengangguran yang tinggi sebagai akibat resesi ekonomi serta untuk memberikan tingkat kehidupan yang lebih baik dan sebagainya juga telah memberikan tekanan kepada pemerintah dalam menciptakan surprise inflation.

Dalam pengantar makalah ini telah disebutkan bahwa upaya memulihkan perekonomian dapat dilakukan melalui kebijakan fiskal seperti melakukan kebijakan defisit spending dengan terus mendorong pengeluaran pemerintah yang lebih besar dari penerimaan, atau dengan melakukan kebijakan moneter dengan mendorong peningkatan jumlah uang beredar. Kebijakan-kebijakan tersebut, timing dan magnitutnya tidak diduga sebelumnya oleh masyarakat, akan menimbulkan surprise inflation atau unexpected inflation..

\section{PILIHAN KEBIJAKAN DALAM PENGENDALIAN INFLASI}

\section{Discretion}

\section{Anticipated}

Kebijakan-kebijakan "discretion" yang bertujuan untuk menciptakan surprise inflation pada awalnya seolah-olah dianggap dapat memberikan manfaat bagi decision maker (bank sentral atau pemerintah) apalagi dari kebijakan meningkatkan inflasi dapat diperoleh seignorage. Namun, apabila dikaji lebih jauh, kebijakan-kebijakan discretion tersebut dapat memberikan kerugian bagi decision maker. Barro \& Gordon (1983), Francesco Lippi (1999) telah membuktikan hal tersebut. Mengacu kepada Loss Function dari pemerintah/bank sentral (lihat persamaan 1), apabila pemerintah/bank sentral melakukan kebijakan discretion maka pemerintah/bank sentral beranggapan bahwa masyarakat tidak mengetahui bahwa pemerintah/bank sentral telah melakukan suatu kebijakan yang dapat menciptakan surprise inflation, namun dalam kenyataannya masyarakat memperoleh informasi yang cukup baik sehingga mengetahui apakah pemerintah melakukan kebijakan yang menimbulkan surprise inflation atau tidak (anticipated).

Dengan melakukan turunan pertama (first differential) terhadap $\mathrm{p}_{\mathrm{t}}$ atas persamaan 1 (proses penurunan lihat lampiran I), maka diperoleh:

$$
\pi_{t}=b / a
$$


Sejak masyarakat diasumsikan dapat mengantisipasi terhadap tingkat inflasi, maka setiap peningkatan actual inflation akan dilakukan penyesuaian peningkatan ekspektasi masyarakat terhadap inflasi (diasumsikan $\pi_{\mathrm{t}}=\pi_{\mathrm{t}}{ }^{\mathrm{e}}$ ). Dari persamaan 3, sejak actual inflasi konstant, maka ekspektasi masyarakat terhadap inflasi di masa datang juga konstan $\left(\pi_{t}{ }^{e}\right.$ konstan). kemudian melakukan substitusi persamaan 3 ke persamaan 1 , maka diperoleh:

$$
Z_{t}=(1 / 2)\left(b^{2} / a\right)
$$

Artinya adalah apabila pemerintah melakukan kebijakan discretion, maka pemerintah akan memperoleh kerugian, yang tercermin dari nilai positif sebesar (1/2) ( $\left.\mathbf{b}^{2} / \mathbf{a}\right)$.

\section{Unanticipated}

Dalam hal apabila masyarakat tidak dapat mengantisipasi terhadap ekspektasi tingkat inflasi di masa datang $\left(\pi_{\mathrm{t}}{ }^{\mathrm{e}}=0\right)$, pemerintah/bank sentral dapat saja tergoda untuk menciptakan surprise inflation, sehingga dalam kasus ini pemerintah/bank sentral dapat dianggap telah melakukan cheating. Pemerintah berpikir bahwa di satu sisi dengan menciptakan surprise inflation akan diperoleh manfaat terhadap peningkatan kinerja ekonomi, dan di sisi lain masyarakat dianggap tidak akan bereaksi terhadap surprise inflation tersebut mengingat ekspektasi masyarakat terhadap inflasi adalah nihil. Dalam kasus pemerintah melakukan cheating maka melalui turunan pertama atas persamaan 1 (proses penurunan lihat lampiran I) akan diperoleh:

$$
\pi_{\mathrm{t}}=(\mathrm{b} / \mathrm{a})
$$

sehingga loss function yang diperoleh pemerintah dengan melakukan cheating adalah :

$$
Z_{t}=-(1 / 2)\left(b^{2} / a\right)
$$

Angka negatif menunjukkan bahwa pemerintah memperoleh manfaat/benefit dari melakukan cheating. Selanjutnya, dapat juga diidentikasikan besarnya godaan bagi pemerintah untuk melakukan cheating, yaitu : 


$$
\begin{aligned}
& \text { Godaan }=E\left(Z_{\text {trule }}-Z_{\text {t cheating }}\right) \\
& =0-\left(-(1 / 2)\left(b^{2} / a\right)\right) \\
& =(1 / 2)\left(b^{2} / a\right)
\end{aligned}
$$

Namun demikian, seandanyai masyarakat ternyata memiliki ekspektasi terhadap inflasi di masa datang $\left(\pi_{\mathrm{t}}{ }^{\mathrm{e}} \neq 0\right)$, maka surprise inflation yang diciptakan pemerintah akan ditanggapi oleh masyarakat dan masyarakat akan cenderung menyesuaikan ekspekatasi mereka sesuai dengan peningkatan actual inflation yang terjadi. Mekanisme ini akan terus berlangsung sampai pemerintah tidak lagi menciptakan surprise inflation mengingat pada saat itu surprise inflation yang diciptakan tidak lagi memberikan manfaat bagi pemerintah. Kondisi dimana pemerintah tidak melakukan surprise inflation adalah sama dengan kondisi dimana pemerintah melakukan kebijakan discretion (merugi, lihat anticipated descretion).

\section{Rule}

Dalam kasus rule, pemerintah/bank sentral (dicision maker) mempunyai komitmen untuk mematuhi aturan main dalam penetapan Inflasi. Dalam hal ini pemerintah tidak akan menciptakan surprise inflation mengingat setiap surprise inflation yang diciptakan pemerintah akan selalu ditanggapi oleh masyarakat yang pada akhirnya menimbulkan spiral inflation, sehingga dalam kasus rule diasumsikan tidak akan ada surprise inflation atau $\pi_{\mathrm{t}}{ }^{\mathrm{e}}-\pi_{\mathrm{t}}=0$, dengan kata lain dalam kasus rule maka:

$$
\pi_{\mathrm{t}}^{\mathrm{e}}=\pi_{\mathrm{t}}
$$

Kembali mengacu pada fungsi persamaan loss function pemerintah (persamaan 1), maka melalui penurunan pertama (lihat lampiran I) akan diperoleh :

$$
\pi_{\mathrm{t}}=0
$$

maka mengacu pada persamaan 5 eskpektasi terhadap inflasi juga dapat dikatakan nihil $\left(\pi_{t}{ }^{e}=0\right)$. Dalam kasus ini, tingkat kerugian yang diperoleh pemerintah dengan menerapkan rule adalah:

$$
\mathrm{Z}_{\mathrm{t}}=0
$$


Jadi dapat dikatakan bahwa pemerintah/bank sentral akan lebih memperoleh manfaat apabila pemerintah konsisten teradap aturan main dalam pencapaian target inflasi dibandingkan apabila pemerintah cenderung menciptakan surprise inflation (discretionary policy) dalam pelaksanaan kebijakannya (bandingkan persamaan 10 dengan persamaan 4). Dengan kata lain, komitmen terhadap aturan main (rule) akan lebih memberikan manfaat dibandingkan dalam kasus discretion di atas.

\section{FAKTOR-FAKTOR YANG DAPAT MENDORONG TERLAMPAUINYA SASARAN INFLASI}

\section{Keinginan Untuk Mendorong Pemulihan Ekonomi Pasca Krisis}

Bank Indonesia telah menetapkan target inflasi di luar pengaruh kebijakan Pemerintah tahun 2001 berkisar antara 4\% - 6\%. Dengan perkiraan dampak dari kebijakan pemerintah di bidang harga dan pendapatan sekitar 2-2,5\% maka inflasi (IHK) diperkirakan mencapai 6-8,5\%. Sejauhmana target tersebut dapat terlampaui?. Ada dua aspek yang perlu diperhatikan, yaitu:

1. Sejauhmana bank sentral memiliki komitmen terhadap target yang telah ditetapkan (rule). Apabila bank sentral terdorong atau terpaksa untuk menciptakan surprise inflation yang tidak diperkirakan sebelumnya atau dengan kata lain sejauh mana kecenderungan untuk melakukan discretionary policies yang berlebihan, maka diperkirakan target tersebut dapat terlampaui.

2. Apakah proses pemulihan ekonomi lebih banyak ditopang oleh peningkatan konsumsi daripada oleh peningkatan investasi, serta sejauhmana gap antara aggregate demand dan aggregate supply tersebut sudah diperhitungkan dalam model penetapan inflasi. Dalam hal kondisi tersebut belum diakomodir dalam model penetapan inflation targeting, maka sangat dimungkinkan hasil target inflasi yang ditetapkan belum menggambarkan kondisi yang sebenarnya. Dapat dimungkinkan target inflasinya terlalu tinggi atau terlalu rendah.

Kemungkinan tingginya tekanan inflasi selama proses pemulihan ekonomi Indonesia cukup besar karena pemulihan ekonomi yang telah berlangsung sejak pertengahan 1999, tampaknya lebih didorong oleh peningkatan konsumsi masyarakat. Berdasarkan tabel di bawah, awal pemulihan ekonomi Indonesia pada tahun 1999 lebih banyak didukung oleh peningkatan konsumsi masyarakat yang tumbuh positif sekitar 3,4\% sementara indikator ekonomi lainnya masih bertumbuh negatif. Keberhasilan bank sentral dalam menekan tingkat suku bunga dan meredam tingkat inflasi, yang pada masa puncaknya 
krisis meningkat begitu tinggi, tampaknya juga mendorong masyarakat untuk meningkatkan pembelian barang dan jasa tersebut (konsumsi).

Tabel 1. Pertumbuhan Ekonomi dari sisi permintaan (y.o.y)

\begin{tabular}{|c|c|c|c|c|c|c|c|c|c|c|}
\hline & \multirow{2}{*}{1996} & \multirow{2}{*}{1997} & \multirow{2}{*}{1998} & \multirow{2}{*}{1999} & \multicolumn{3}{|c|}{2000} & \multicolumn{3}{|c|}{2001} \\
\hline & & & & & 1 & 2 & 3 & 4 & $1^{*}$ & $2 * *$ \\
\hline \multicolumn{11}{|l|}{ Growth } \\
\hline PDB & 7.8 & 4.7 & -13.0 & 0.3 & 4.2 & 5.2 & 4.4 & 5.2 & 4.0 & $3.0-4.0$ \\
\hline Konsumsi & 8.9 & 7.0 & -7.2 & 3.4 & 2.6 & 3.0 & 4.7 & 5.3 & 4.9 & $2.0-3.0$ \\
\hline Investasi & 14.5 & 8.6 & -33.0 & -20.0 & 13.1 & 20.7 & 22.3 & 15.8 & 10.2 & $7.1-8.1$ \\
\hline Ekspor & 7.6 & 7.8 & 11.2 & -31.6 & 15.1 & 21.2 & 14.1 & 14.2 & 11.7 & $7.9-8.9$ \\
\hline Impor & 6.9 & 14.7 & -5.3 & -40.7 & 5.0 & 3.9 & 20.2 & 44.2 & 34.1 & $14.1-15.1$ \\
\hline
\end{tabular}

Sumber : Bank Indonesia

Peningkatan pembelian barang dan jasa dapat dicerminkan dari beberapa indikator diantaranya meningkatnya penjualan kendaraan bermotor dan penjualan eceran serta peningatan kredit konsumsi perbankan.

Grafik 1.

Penjualan Kendaraan Bermotor

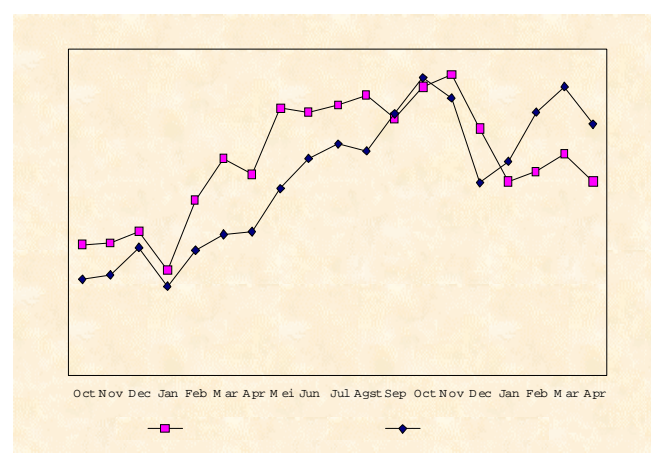

Sumber : Bank Indonesia
Grafik 2.

Survey Penjualan Eceran

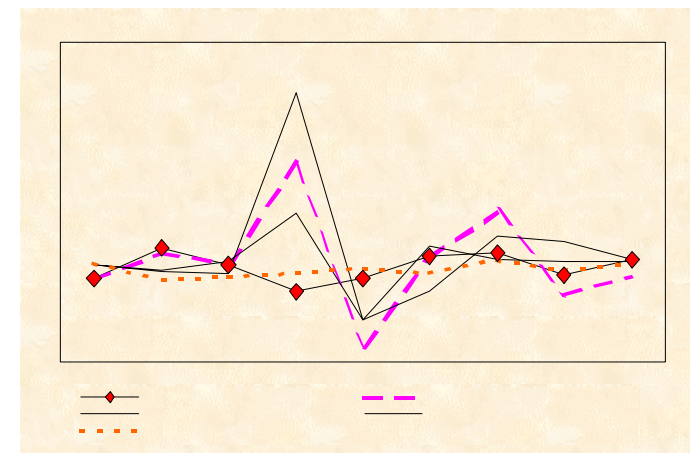

Sumber : Bank Indonesia

Sementara untuk tahun 2000 dan 2001, meskipun tingkat investasi telah bertumbuh positif, namun ekonomi Indonesia dihantui oleh terus melemahnya nilai tukar rupiah yang diikuti oleh meningkatnya kegiatan spekulasi di pasar valuta asing. Selain itu, meningkatnya faktor risiko dan ketidakpastian yang terjadi pada periode dimaksud telah mendorong 
masyarakat cenderung untuk lebih berjaga-jaga dan meningkatkan portofolionya dalam memegang cash. Dalam kondisi demikian tekanan-tekanan terhadap meningkatnya tingkat inflasi semakin tinggi baik disebabkan oleh imported inflation maupun oleh demand driven inflation lainnya. Sementara itu, tekanan dari sektor fiskal untuk menghilangkan subsidi telah pula mendorong peningkatan inflasi. Dalam kondisi yang demikian, upaya yang dilakukan oleh bank sentral untuk meredam meningkatnya laju inflasi yang berlebihan adalah dengan mengendalikan jumlah uang beredar (uang primer) dengan konsekuensi terhadap peningkatan suku bunga, serta didukung oleh upaya sterilisasi valuta asing dalam mengendalikan jumlah uang beredar dimaksud.

\section{Keinginan untuk Menyelamatkan Sektor Perbankan Selama Krisis}

Salah satu faktor yang menghambat berlangsungnya pemulihan ekonomi adalah belum berjalannya fungsi intermediasi perbankan secara optimal. Faktor yang diperkirakan menyebabkan hal tersebut diantaranya adalah : (1) Adanya kendala internal bank sendiri seperti minimnnya Capital Adequacy Ratio (CAR) bank, keterbatasan batas Maksimum Pemberian Kredit (BMPK) dan lain-lain. (2) Tingginya risiko usaha sebagai akibat tingginya faktor risiko dan ketidakpastian baik di bidang politik, sosial dan keamanan. (3) Lemahnya absorpsi sektor riil, dan (4) belum berkembangnya pasar sekunder obligasi Pemerintah.

Belum pulihnya fungsi intermediasi perbankan pada gilirannya akan mengurangi kemampuan bank dalam memperoleh keuntungan. Beberapa bank pada akhirnya mengalihkan penanaman dananya pada obligasi Pemerintah dan Sertifikat Bank Indonesia (SBI). Dalam kondisi tingkat suku bunga cenderung meningkat, maka bank-bank yang cenderung menanamkan dananya pada fixed rate bond akan mengalami kerugian, yang pada gilirannya akan mengganggu keuangan bank itu sendiri. Apabila bank dimaksud terus menerus menghadapi kondisi seperti demikian, maka sangat dimungkinkan bank tersebut pada akhirnya akan menghadapi masalah likuiditas yang berkepanjangan. Sementara di sisi lain, tingginya outstanding kredit macet di perbankan, mengharuskan bank-bank melakukan pencadangan atas kredit macet. Apabila bank tidak mampu menyediakan dana segar (fresh fund) untuk pencadangan tersebut, maka pada gilirannya akan menggerogoti permodalan bank dan keuntungan bank yang sudah kecil. Pada akhirnya bank akan menghadapi masalah struktural dalam bentuk ketidakmampuan melunasi kewajiban jangka pendek (ilikuid) dan jangka panjanganya (insolven).

Kurang mampunya bank menjalankan fungsi sebagaimana seharusnya, akan berdampak pada pembiayaan pembangunan, mengingat hampir sebagian besar (kurang lebih $70-75 \%$ ) pembiayaan dunia usaha adalah berasal dari sektor perbankan. Pemerintah dan bank sentral akan dihadapkan pada situasi yang dilematis. Godaan untuk "membantu" 
bank-bank khususnya bank yang sedang mengalami kesulitan likuiditas, tampaknya cukup tinggi untuk mencegah runtuhnya sistem perbankan secara keseluruhan dan untuk mempercepat proses program restrukturisasi perbankan. Pada akhirnya dimungkinkan terjadinya bleeding dana ke perbankan dalam rangka memulihkan sektor perbankan, namun demikian hal tersebut akan memberikan tekanan terhadap meningkatnya tingkat inflasi.

\section{MENCIPTAKAN TARGET YANG KREDIBEL}

Ada dua hal yang harus dipertimbangkan bagi pemerintah/bank sentral dalam menjalankan inflation targetting dalam situasi pemulihan ekonomi, yaitu:

1. Bagaimana menciptakan target yang credible. Yang dimaksud dalam poin ini adalah sampai sejauhmana model yang digunakan dalam menetapkan inflasi sudah memperhitungkan konsekuensi dari adanya proses pemulihan ekonomi.

2. Sejauhmana komitmen pemerintah/bank sentral untuk tidak melakukan cheating yang pada akhirnya menimbulkan discretionary policies. Artinya sejauhmana pemerintah/ bank sentral tidak tergoda untuk melakukan cheating.

Terdapat beberapa model yang dapat digunakan untuk dijadikan dasar dalam menetapkan target inflasi, diataranya yaitu:

\section{Non Conservative Central Bank dan Conservative Central Bank}

Barro \& Gordon (1983) mengemukakan model Non Conservative Central Bank. Dalam model tersebut Barro \& Gordon memberikan bobot yang kurang lebih sebanding terhadap stabilitas inflasi dan stabilitas output. Sementara, Rogoff (1985) mengemukakan model Conservative Central Bank dengan memberikan bobot atau perhatian yang lebih kepada stabilitas inflasi dari pada stabilitas output. Masing-masing model dimaksud adalah :

Non Conservative Central Bank:

$$
Z_{t}=(1 / 2)\left(\pi_{t}-\pi^{*}\right)+(x / 2)\left(Y_{t}-Y^{*}\right)^{2}
$$

Conservative Central Bank:

$$
Z_{t}=((1+\varepsilon) / 2)\left(\pi_{t}-\pi^{*}\right)+(x / 2)\left(Y_{t}-Y^{*}\right)^{2}
$$


Dimana $Y_{t}=\pi_{t}-\pi^{e}+\mu_{t}$ (Taylor Model)

Keterangan :

$\pi_{\mathrm{t}}=$ Inflati aktual, $\pi^{*}=$ Inflasi yang dikehendaki (target), $\mathrm{Y}_{\mathrm{t}}=$ output aktual,

$\mathrm{Y}^{*}=$ Output yang dikehendaki, $\mathrm{x}=$ porsi bobot untuk output stabilization,

$\varepsilon=$ Tambahan bobot untuk inflasi $\mu_{\mathrm{t}}=$ Faktor lain yang mempengaruhi output

Dengan menggunakan metode matematik (lihat lampiran II), maka akan diperoleh:

$\begin{array}{lccc} & \text { Non Conservative } & & \begin{array}{c}\text { Conservative } \\ (\mathrm{x} /(1+\mathrm{x})) \mathrm{Y}^{*}\end{array} \\ \text { Inflation Bias } & > & (\mathrm{x} /(1+\mathrm{x}+\varepsilon)) \mathrm{Y}^{*} \\ \text { Inflation Variance } & (\mathrm{x} /(1+\mathrm{x})) \sigma_{\mathrm{u}}{ }^{2} & > & (\mathrm{x} /(1+\mathrm{x}+\varepsilon)) \sigma_{\mathrm{u}}{ }^{2} \\ \text { Output Variance } & (1 /(1+\mathrm{x}))^{2} \sigma_{\mathrm{u}}{ }^{2} & < & (1 /(1+\mathrm{x}+\varepsilon))^{2} \sigma_{\mathrm{u}}{ }^{2}\end{array}$

Atau dalam ilustrasi grafis adalah :

Gambar 3 : Perbandingan Non Conseravitve dan Concervative



Keterangan :

$\begin{array}{lccc} & \text { Non Conservative } & & \text { Conservative } \\ \text { Inflation Bias } & \mathrm{E}(\pi)_{1} & > & \mathrm{E}(\pi)_{2} \\ \text { Inflation Variance } & \pi^{*}-\mathrm{E}(\pi)_{1} & > & \pi^{*}-\mathrm{E}(\pi)_{2} \\ \text { Output Variance } & \mathrm{b}-\mathrm{c} & < & \mathrm{a}-\mathrm{d}\end{array}$


Target inflasi yang dihasilkan melalui model conservative central bank cenderung lebih kecil dari non conservative central bank, dengan variance yang lebih kecil, yang artinya bahwa kemungkinan deviasi inflasi aktual dari target lebih kecil. Namun demikian, kemungkinan terjadinya gejolak output lebih besar di conservative dibandingkan non conservative.

\section{Accountable Central Banker}

Walsh (1995) mengemukakan model accountable central banker dengan memberikan perhatian yang seimbang antara pencapaian target inflasi dan stabilitas output atau sama dengan model yang dikemukakan oleh Barro \& Gordon. Namun, Walsh juga menambahkan adanya unsur pinalti/sanksi. Apabila bank sentral tidak dapat mencapai target maka akan ada pinalti terhadap bank sentral tersebut. Secara matematis model Walsh dikemukakan sebagai berikut:

$$
Z_{t}=(1 / 2)\left(\pi_{t}-\pi^{*}\right)+(x / 2)\left(Y_{t}-Y^{*}\right)^{2}+\chi Y^{*} \pi_{t}
$$

Dimana $\chi \mathrm{Y}^{*} \pi_{\mathrm{t}}$ adalah penalti atau sanksi yang dikenakan. Dengan menggunakan metode matematis, maka diperoleh:

$$
\begin{array}{lll}
\text { Inflation Variance } & : & \text { nihil dimana } \pi^{\mathrm{e}}=\pi^{*} \text { (inflasi yang diinginkan) } \\
\text { Output Variance } & : \quad(1 /(1+\mathrm{x}))^{2} \sigma_{\mathrm{u}}{ }^{2}
\end{array}
$$

Atau sama dengan non conservative central bank.

Accountable model memberikan kepastian bahwa variasi terhadap inflasi akan nihil karena bank sentral akan selalu dituntut untuk mencapai target yang telah ditetapkan, apabila target tersebut tidak tercapai (under performance) maka akan ada pengenaan sanksi terhadap bank sentral tersebut baik berupa penggantian manajemen, pengurangan gaji dan sebaginya. Sementara di sisi lain, model tersebut dapat menekan variance terhadap output sama dengan output variance seperti pada model non conservative central bank.

Dari penjelasan di atas tersebut, perbandingan antara ketiga model inflation targeting secara umum adalah:

$$
\text { Non Conservative Conservative Accountabel Model }
$$
Inflation Variance
$(\mathrm{x} /(1+\mathrm{x})) \sigma_{\mathrm{u}}^{2} \quad>$
$(\mathrm{x} /(1+\mathrm{x}+\varepsilon)) \sigma_{\mathrm{u}}{ }^{2}$
Nihil
Output Variance
$(1 /(1+x))^{2} \sigma_{u}{ }^{2}<$
$(1 /(1+x+\varepsilon))^{2} \sigma_{u}{ }^{2}$
$(1 /(1+x))^{2} \sigma_{u}{ }^{2}$ 


\section{PENUTUP}

Sebagai penutup dari uraian di atas adalah sebagai berikut:

1. Proses pemulihan ekonomi yang sedang terjadi saat ini diikuti oleh meningkatnya tekanan-tekanan terhadap tingkat inflasi, mengingat meningkatnya permintaan agregat belum diikuti oleh peningkatnya sisi penawaran sebagai akibat dari terhambatnya sektor produksi. Sementara, upaya segera untuk merstrukturisasi dunia perbankan dalam rangka mendukung proses pemulihan ekonomi, telah menempatkan Bank Indonesia pada situasi yang dilematis, antara mempertahankan dari terpuruknya dunia perbankan dan menjaga tidak berlebihnya supply jumlah uang beredar di pasar si satu sisi, akibat bantuan kepada bank untuk mengatasi kesulitan likuiditasnya di sisi lain. Adanya bleeding dana ke sektor perbankan dalam rangka mengatasi kesulitas likuiditas akan memberikan tekanan-tekanan terhadap meningkatnya tingkat inflasi.

2. Guna menekan adanya discretionary policy, tampaknya perlu ada komitmen dari Bank Indonesia untuk tetap patuh pada aturan main. Untuk menjaga komitmen tersebut, diperlukan enforcement baik berasal dari intern Bank Indonesia sendiri maupun dari pihak luar. Berkaitan dengan hal tersebut, tampaknya accountable model dalam penetapan model inflation targeting dapat dijadikan opsi dalam model inflation targeting Bank Indonesia. Selain disatu sisi dapat memaksa Bank Indonesai tetap mengacu pada pencapaian target inflasi, karena adanya sanksi seandainya target tersebut tidak tercapai, di sisi lain dapat menjaga stabilitas pertumbuhan ekonomi yang saat ini sangat diperlukan dalam menjaga keberlangsungan pemulihan ekonomi.

\section{DAFTAR PUSTAKA}

1. Allen, William A, (1999), Inflation Targetting : The British Experience, Handbooks in Central Banking Lecture Series No. 1, Centre for Central Banking Studies, Bank of England.

2. Barro, R.J, Gordon, D.B (1983)," Rules, Discretion and Reputation in A Model of Monetary Policy", Journal of Monetary Economics 12, 101 - 121.

3. Debelle, G (1997),"Inflation Targeting in Practice", IMF Working paper, WP/97/35.

4. De Grauwe, P. (1997), The Economics of Monetary Integration, Third Edition, Oxford University Press. 
5. Lippi, F (1999), Central Bank Independence, Targets and Credibility, Edward Elgar, Cheltenham, UK.

6. McCallum, B.T (2000), " The Present and Future of Monetary Policy Rules", Cargegie Mellon University and National Bureau of Economic Research.

7. Mishkin, F.S., Posen A.S. (1997), "Inflation Targeting: Lesson from Four Countries", Economic Policy Review, Federal Reserve Bank of New Yorks 3, 9- 110.

8. Rogoff, K (1985), “The Optimal Degree of Commitment to An Intermediate Monetary Target", Quarterly Journal of Economics 100, 1169 - 1190.

9. Walsh, C. (1995), "Optimal Contract for Independent Central Banks", American Economic Review 85, $150-167$.

10. ................., Indikator Terkini Ekonomi dan Moneter, Sektor Moneter, Bank Indonesia, 1999 - 2001.

11. ................,Perkembangan dan Kebijakan Perbankan, Bahan Rapat Dewan Gubernur, Sektor Perbankan, Bank Indonesia, 1999 - 2001.

12. ..............., Laporan Triwulanan : Perkembangan Moneter, Sistem Pembayaran dan Perbankan, Bank Indonesia, 1999 - 2001. 


\section{LAMPIRAN I}

\section{Proses Matematis untuk Anticipated Discretion}

Government's Loss Function :

$Z_{t}=(a / 2)\left(\pi_{t}\right)^{2}-b\left(\pi_{t}-\pi_{t}^{e}\right)$

Proses turunan pertama :

$$
\begin{aligned}
& \delta Z_{t} / \delta \pi_{t}=a\left(\pi_{t}\right)-b=0 \\
&=a\left(\pi_{t}\right)=b \\
&\left(\pi_{t}\right)=(b / a) \ldots
\end{aligned}
$$

$\operatorname{sejak}\left(\pi_{t}\right)=\left(\pi_{t}^{e}\right)$, maka $\pi_{t}^{e}=(b / a)$

Proses substitusi ke loss function :

$$
\begin{aligned}
& Z_{t}=(a / 2)\left(\pi_{t}\right)^{2}-b\left(\pi_{t}-\pi_{t}{ }^{e}\right) \\
& =(\mathrm{a} / 2)(\mathrm{b} / \mathrm{a})^{2}-\mathrm{b}((\mathrm{b} / \mathrm{a})-(\mathrm{b} / \mathrm{a})) \\
& =(\mathrm{a} / 2)(\mathrm{b} / \mathrm{a})^{2}-0 \\
& =(1 / 2)\left(b^{2} / a\right) \text {. }
\end{aligned}
$$

\section{Proses Matematis untuk Unanticipated Discretion}

Government's Loss Function :

$Z_{t}=(a / 2)\left(\pi_{t}\right)^{2}-b\left(\pi_{t}-\pi_{t}{ }^{e}\right)$

Proses turunan pertama :

Sejak $\pi_{\mathrm{t}}^{\mathrm{e}}=0$ .(e) 


$$
\begin{aligned}
& \delta \mathrm{Z}_{\mathrm{t}} / \delta \pi_{\mathrm{t}}=\mathrm{a}\left(\pi_{\mathrm{t}}\right)-\mathrm{b}=0 \\
& =\mathrm{a}\left(\pi_{\mathrm{t}}\right)=\mathrm{b} \\
& \left(\pi_{t}\right)=(b / a)
\end{aligned}
$$

Proses substitusi ke loss function :

$$
\begin{aligned}
& Z_{t}=(a / 2)\left(\pi_{t}\right)^{2}-b\left(\pi_{t}-\pi_{t}{ }^{e}\right) \quad \text { karena } \pi_{t}{ }^{e}=0 \text {, maka } \\
& =(\mathrm{a} / 2)(\mathrm{b} / \mathrm{a})^{2}-\mathrm{b}((\mathrm{b} / \mathrm{a})-0) \\
& =(1 / 2)(b / a)^{2}-\left(b^{2} / a\right) \\
& =-(1 / 2)\left(b^{2} / a\right)
\end{aligned}
$$

\section{Proses Matematis untuk Rule}

Government's Loss Function :

$\mathrm{Z}_{\mathrm{t}}=(\mathrm{a} / 2)\left(\pi_{\mathrm{t}}\right)^{2}-\mathrm{b}\left(\pi_{\mathrm{t}}-\pi_{\mathrm{t}}{ }^{\mathrm{e}}\right)$

Proses turunan pertama:

Sejak $\pi_{t}^{e}=\pi_{t}$

$$
\begin{aligned}
\delta Z_{t} / \delta \pi_{t} & =a\left(\pi_{t}\right)=0 \\
& =\left(\pi_{t}\right)=0 \ldots
\end{aligned}
$$

Proses substitusi ke loss function :

$$
\begin{aligned}
& \mathrm{Z}_{\mathrm{t}}=(\mathrm{a} / 2)\left(\pi_{\mathrm{t}}\right)^{2}-\mathrm{b}\left(\pi_{\mathrm{t}}-\pi_{\mathrm{t}}^{\mathrm{e}}\right) \quad \text { karena } \pi_{\mathrm{t}}^{\mathrm{e}}=\pi_{\mathrm{t}}=0 \text {, maka } \\
& =(\mathrm{a} / 2)(0)^{2}-\mathrm{b}((0)-0) \\
& =0
\end{aligned}
$$




\section{LAMPIRAN II}

\section{Proses Matematis untuk Conservative Model}

a. Conservative Model :

$Z_{t}=((1+\varepsilon) / 2)\left(\pi_{t}-\pi^{*}\right)+(x / 2)\left(Y_{t}-Y^{*}\right)^{2}$

b. Proses Turunan Pertama :

$\delta Z_{\mathrm{t}} / \delta \pi_{\mathrm{t}}=(1+\varepsilon) \pi_{\mathrm{t}}-(1+\varepsilon) \pi^{*}+\mathrm{x} \pi_{\mathrm{t}}-\mathrm{x} \pi^{*}-\mathrm{x} Y^{*}+\mathrm{x} Y^{*}=0$

$$
\pi_{\mathrm{t}}=\pi^{*}+(\mathrm{x} /(1+\varepsilon+\mathrm{x})) \mathrm{Y}^{*}-(\mathrm{x} /(1+\varepsilon+\mathrm{x})) \mu
$$

c. Rational expectation dari persamaan $(1)$, dimana $E\left(\mu_{t}\right)=0$, maka :

$$
\pi_{\mathrm{t}}^{\mathrm{e}}=\pi^{*}+(\mathrm{x} /(1+\varepsilon+\mathrm{x})) Y^{*}
$$

d. Substitusi persamaan (l) dan (m) kedalam persamaan Taylor

$$
\begin{aligned}
& \mathrm{Y}_{\mathrm{t}}=\pi_{\mathrm{t}}-\pi^{\mathrm{e}}+\mu_{\mathrm{t}} \quad \text { (Taylor Model) } \\
& =\pi^{*}+(\mathrm{x} /(1+\varepsilon+\mathrm{x})) \mathrm{Y}^{*}-(\mathrm{x} /(1+\varepsilon+\mathrm{x})) \mu_{\mathrm{t}}-\pi^{*}-(\mathrm{x} /(1+\varepsilon+\mathrm{x})) \mathrm{Y}^{*}+\mu_{\mathrm{t}} \\
& =[(1+\varepsilon) / 1+\varepsilon+x)] \mu_{t}
\end{aligned}
$$

e. Inflation Bias, variance of Inflation dan variance of output

Inflation bias :

$$
\begin{aligned}
& \pi_{\mathrm{t}}^{\mathrm{e}}=\pi^{*}+(\mathrm{x} /(1+\varepsilon+\mathrm{x})) \mathrm{Y}^{*} \\
& \pi_{\mathrm{t}}^{\mathrm{e}}-\pi^{*}=\text { Inflation Bias }=(\mathrm{x} /(\mathbf{1}+\boldsymbol{\varepsilon}+\mathrm{x})) \mathrm{Y}^{*} \\
& \text { Variance of Inflation: } \\
& \pi_{\mathrm{t}}=\pi^{*}+(\mathrm{x} /(1+\varepsilon+\mathrm{x})) \mathrm{Y}^{*}-(\mathrm{x} /(1+\varepsilon+\mathrm{x})) \mu_{\mathrm{t}} \\
& \sigma \pi=0+0+(\mathrm{x} /(1+\mathrm{e}+\mathrm{x}))^{2} \sigma \mu^{2} \\
& \sigma \pi=(\mathrm{x} /(\mathbf{1}+\boldsymbol{\varepsilon}+\mathrm{x}))^{2} \sigma \mu^{2}
\end{aligned}
$$


Variance of output :

$\mathrm{Yt}=[(1+\varepsilon) / 1+\varepsilon+\mathrm{x})] \mu_{\mathrm{t}}$

$\sigma_{\mathrm{y}}=[(1+\varepsilon) /(1+\varepsilon+\mathrm{x})]^{2} \sigma \mu^{2}$

Dengan melakukan tahapan yang sama, dapat dilakukan terhadap non conservative model dan accountable model untuk mencari variance of inflation dan variance of output. Hasil untuk ketiga model seperti yang telah dikemukakan pada halaman 12. 